\title{
Dose-response effect of 3-nitrooxypropanol on enteric methane emissions in dairy cows
}

\author{
A. Melgar, ${ }^{1}$ K. C. Welter, ${ }^{1,2}$ K. Nedelkov, ${ }^{1,3}$ C. M. M. R. Martins,,${ }^{1,4}$ M. T. Harper, ${ }^{1}$ J. Oh, ${ }^{1}$ S. E. Räisänen, ${ }^{1}$ \\ X. Chen, ${ }^{1,5}$ S. F. Cueva, ${ }^{1,6}$ S. Duval, ${ }^{7}$ and A. N. Hristov ${ }^{1 *}$ \\ ${ }^{1}$ Department of Animal Science, The Pennsylvania State University, University Park 16802 \\ ${ }^{2}$ Department of Animal Science, School of Food Engineering and Animal Science, University of São Paulo, Pirassununga 13635-900, São Paulo, \\ Brazil \\ ${ }^{3}$ Department of Animal Husbandry, Faculty of Veterinary Medicine, Trakia University, Stara Zagora 6000, Bulgaria \\ ${ }^{4}$ Department of Animal Nutrition and Production, School of Veterinary Medicine and Animal Science, University of São Paulo, \\ Pirassununga 13635-900, São Paulo, Brazil \\ ${ }^{5}$ School of Computing, University of Ulster, Newtonabbey, Co. Antrim, BT37 0QB, United Kingdom \\ ${ }^{6}$ Panamerican Agricultural University, Zamorano, Francisco Morazan, Km 30, Tegucigalpa 11101, Honduras \\ ${ }^{7}$ Research Centre for Animal Nutrition and Health, DSM Nutritional Products, Saint Louis Cedex 68305, France
}

\begin{abstract}
This experiment was designed to test the effect of inclusion rate of 3-nitrooxypropanol (3-NOP), a methane inhibitor, on enteric methane emissions in dairy cows. The study was conducted with 49 multiparous Holstein cows in a randomized complete block design in 2 phases; phase 1 was with 28 cows, and phase 2 with 21 cows. Cows were fed a basal total mixed ration ad libitum and were blocked based on days in milk, milk yield, and enteric methane emissions during a 14-d covariate period. Treatments were control (no 3-NOP) and $40,60,80,100,150$, and $200 \mathrm{mg}$ of $3-\mathrm{NOP} / \mathrm{kg}$ of feed dry matter. Following a 14-d adaptation period, enteric gaseous emissions (methane, carbon dioxide, and hydrogen) were measured using the GreenFeed system (C-Lock Inc., Rapid City, SD) over a 3-d period. Compared with the control, inclusion rate of 3-NOP quadratically decreased daily enteric methane emissions from 22 to $40 \%$. Maximum mitigation effect was achieved with the 3 highest 3-NOP doses (with no statistical difference among 100, 150, and $200 \mathrm{mg} /$ $\mathrm{kg}$ ). The decrease in methane emission yield and emission intensity ranged from 16 to $36 \%$ and from 25 to $45 \%$, respectively. Emissions of hydrogen quadratically increased 6- to 10-fold, compared with the control; the maximum increase was with $150 \mathrm{mg} / \mathrm{kg} 3$-NOP. Treatment did not affect daily emissions of carbon dioxide, but a linear increase in carbon dioxide emission yield was observed with increasing 3-NOP doses. Dry matter intake and milk yield of the cows was not affected by 3-NOP. Milk fat concentration and yield were increased
\end{abstract}

Received November 2, 2019.

Accepted February 22, 2020.

*Corresponding author: anh13@psu.edu by 3 -NOP due to increased concentration of de novo synthetized short-chain fatty acids in milk. Inclusion of 3 -NOP also tended to increase milk urea nitrogen but had no other effects on milk components. In this shortterm experiment, 3-NOP decreased enteric methane emissions without affecting dry matter intake or milk yield and increased milk fat in dairy cows. Maximum mitigation effect was achieved at 100 to $200 \mathrm{mg} / \mathrm{kg}$ of feed dry matter.

Key words: methane, 3-nitrooxypropanol, dairy cattle

\section{INTRODUCTION}

The anti-methanogenic effect of 3-nitrooxypropanol (3-NOP) has been consistent in cattle and its enteric $\mathrm{CH}_{4}$ mitigation potential has been confirmed in previous long-term studies with lactating dairy cows (Hristov et al., 2015a; Van Wesemael et al., 2019; Melgar et al., 2019, 2020) and beef cattle (Romero-Pérez et al., 2014, 2015). A meta-analysis concluded that inclusion level and administration technique appeared to affect the extent of $\mathrm{CH}_{4}$ mitigation by 3-NOP in cattle (Dijkstra et al., 2018). Due to its molecular structure, 3-NOP is highly soluble and rapidly metabolized in the rumen (Duin et al., 2016). The extent of mitigation effect of 3 -NOP on enteric $\mathrm{CH}_{4}$ in dairy cows has been reported to range from $7 \%$, when administered as a pulse-dose directly into the rumen via the fistula (Reynolds et al., 2014), to $60 \%$, when mixed with the TMR and fed continuously with the feed (Haisan et al., 2014). Consistent with these reports, results from Hristov et al. (2015a) and 3 follow-up studies from our laboratory (Lopes et al., 2016; Melgar et al., 2019, 2020) demonstrated a persistent $\mathrm{CH}_{4}$ mitigation effect of 3-NOP when administered through the TMR. In beef cattle, Romero-Pérez et al. (2015) observed a greater reduction in $\mathrm{CH}_{4}$ emis- 
sions $(59 \%)$ when $280 \mathrm{mg} / \mathrm{kg}$ of $3-\mathrm{NOP}$ was mixed with the TMR than top-dressing 3-NOP at up to $345 \mathrm{mg} / \mathrm{kg}$ of feed DM in animals fed the same backgrounding diet (33\%; Romero-Pérez et al., 2014). It has been shown that the antimethanogenic effect of $3-\mathrm{NOP}$ appears to be smaller in beef than in dairy cattle (Dijkstra et al., 2018). Long-term experiments with 3-NOP in both beef (Romero-Pérez et al., 2015) and dairy cattle (unpublished data from Melgar et al., 2020) have also shown that enteric $\mathrm{CH}_{4}$ emissions returned to basal levels within a week after 3 -NOP administration was discontinued.

Dose-response effects of 3-NOP have been studied in beef cattle (Romero-Pérez et al., 2014; Vyas et al., 2016) and dairy cows (Reynolds et al., 2014; Hristov et al., 2015a). No dose-dependent effect of 3-NOP was reported in the Reynolds et al. (2014) study after administering 3 -NOP directly into the rumen at a rate of 500 and $2,500 \mathrm{mg} / \mathrm{d}$, representing 27 and $135 \mathrm{mg} /$ $\mathrm{kg}$ of feed DM, respectively. Hristov et al. (2015a) evaluated 3 levels of inclusion of 3-NOP (40,60, and 80 $\mathrm{mg} / \mathrm{kg}$ of feed DM) in mid- to late-lactation cows and observed a similar decrease in enteric $\mathrm{CH}_{4}$ emissions, yield, and intensity with all 3-NOP doses (although a statistically significant linear effect was reported). In the latter study, 3-NOP was administered through the TMR, which allowed continuous consumption of the compound throughout the day, whereas Reynolds et al. (2014) used a pulse-dose, which could explain the lack of dose effect of 3-NOP. None of the studies with dairy cows, however, have investigated response to 3 -NOP included in doses of up to $200 \mathrm{mg} / \mathrm{kg}$ of TMR DM.

Therefore, the objective of this study was to investigate the effect of 3 -NOP, administered through the TMR in doses of up to $200 \mathrm{mg} / \mathrm{kg}$ of feed DM, on enteric $\mathrm{CH}_{4}$ emissions, DMI, and lactational performance of dairy cows. We hypothesized that within the range of application rates studied, 3-NOP would linearly decrease enteric $\mathrm{CH}_{4}$ emissions without affecting DMI and lactational performance of the cows.

\section{MATERIALS AND METHODS}

Animals involved in this experiment were cared for according to the guidelines of The Pennsylvania State University Institutional Animal Care and Use Committee. The committee reviewed and approved the experiment and all procedures involving animals.

\section{Experimental Design, Diet, and Treatment}

The study was conducted with 49 multiparous Holstein cows $(155 \pm 7.7 \mathrm{DIM}, 634 \pm 8.1 \mathrm{~kg}$ of BW, and $44 \pm 1.1 \mathrm{~kg} / \mathrm{d}$ milk yield at the beginning of the experi- ment) in a randomized complete block design at The Pennsylvania State University's Dairy Teaching and Research Center's tiestall barn (University Park, PA). Cows were blocked into 7 blocks of 7 animals each, based on DIM, milk yield, and enteric $\mathrm{CH}_{4}$ emissions during a 14-d covariate period. The experiment was conducted in 2 phases due to limited tiestall space for the number of cows enrolled in the study; phase 1 was with 28 cows (blocks 1 to 4 ) and phase 2 was with 21 cows (blocks 5 to 7 ). Within block, cows were randomly assigned to 1 of 7 treatments: control (placebo, no $3-\mathrm{NOP}$ ) and 40, $60,80,100,150$, and $200 \mathrm{mg}$ of $3-\mathrm{NOP} / \mathrm{kg}$ of feed $\mathrm{DM}$ (40NOP, 60NOP, 80NOP, 100NOP, 150NOP, and 200NOP, respectively). Each phase consisted of 14-d covariate and 17-d treatment periods.

The ration was fed as TMR and 3-NOP was incorporated into the TMR through a premix containing $(\%$, DM basis) $60 \%$ ground corn grain, $5 \%$ soybean oil, $15 \%$ dry molasses, and $20 \%$ of an active or placebo supplement (DSM Nutritional Products, Basel, Switzerland). The active supplement contained $10.9 \% 3$-NOP on $\mathrm{SiO}_{2}$ and propylene glycol and the placebo supplement contained $\mathrm{SiO}_{2}$ and propylene glycol only. Two premixes were prepared (i.e., control and 3 -NOP premix) and 3 -NOP treatment doses were achieved by mixing proportions of the 2 supplements (control/3-NOP supplement: $100 / 0,80 / 20,70 / 30,60 / 40,50 / 50,25 / 75$, and $0 / 100 \%$ for control, $40 \mathrm{NOP}, 60 \mathrm{NOP}, 80 \mathrm{NOP}, 100 \mathrm{NOP}$, $150 \mathrm{NOP}$, and $200 \mathrm{NOP}$, respectively). The premixes were prepared twice weekly, kept at $4^{\circ} \mathrm{C}$ in sealed containers with no headspace, and mixed daily with the TMR before feeding to deliver the final 3-NOP application rate as indicated above.

Cows were housed in a tiestall barn, fed ad libitum once daily at approximately $0800 \mathrm{~h}$ targeting $10 \%$ refusals and had free access to drinking water. Cows were fed a basal TMR (Table 1) for $14 \mathrm{~d}$ before the beginning of the treatment period (i.e., covariate period). The basal TMR was formulated to meet or exceed the $\mathrm{NE}_{\mathrm{L}}$ and MP requirements of a cow producing $44 \mathrm{~kg} / \mathrm{d}$ of milk with $3.50 \%$ milk fat and $3.05 \%$ milk true protein and consuming $26 \mathrm{~kg} / \mathrm{d}$ of feed DM according to NRC (2001). The composition of the basal TMR was the same in both phases of the experiment. Feed was pushed up to the cows 4 to 6 times daily. The basal TMR was prepared using a stationary mixer (Electra-Mix, model 1062, I. H. Rissler, Mohnton, PA) and separate mixers (Rissler Mobile TMR Mixer Model 1050, I. H. Rissler) were used to mix the control and 3-NOP TMR. The mixing order for the 6 TMR containing 3-NOP (i.e., $40 \mathrm{NOP}, 60 \mathrm{NOP}, 80 \mathrm{NOP}, 100 \mathrm{NOP}, 150 \mathrm{NOP}$, and 200NOP) was from lowest to the highest concentration of 3-NOP. Cows were milked twice daily at 0600 and 1800 h. Milk from 3-NOP fed cows was discarded for 
the duration of the study and for an additional $7 \mathrm{~d}$ upon completion of the study.

\section{Sampling and Measurements}

Diet and Feed Ingredients. The amount of feed offered and refused was weighed individually and recorded for each cow at the time of feeding to measure daily as-fed intake during the entire experiment. Dry matter content of the TMR and refusals was determined weekly and used to calculate DMI from the as-fed TMR intake. Samples of the forages and concentrate feeds were collected once weekly and samples of the TMR and refusals were collected twice weekly and stored at $-20^{\circ} \mathrm{C}$. Feed samples were later dried for $72 \mathrm{~h}$ at $55^{\circ} \mathrm{C}$ in a forced-air oven and ground in a Wiley Mill (Thomas Scientific, Swedesboro, NJ) through a 1-mm sieve for further analysis. Forages and concentrate feeds were composited (equal DM weight basis) per phase and submitted to Cumberland Valley Analytical Services (CVAS, 2018) for wet chemistry analyses of CP (method 990.03; AOAC International, 2000), amylase-treated NDF (Van Soest et al., 1991), ether extract (method 2003.05; AOAC International, 2006), ADF (method 973.18; AOAC International, 2000), ash (method 942.05; AOAC International, 2000), minerals (method 985.01; AOAC International, 2000), and estimated NFC (NRC, 2001). Starch was analyzed as described in Hall (2009). The chemical composition of the basal diet (i.e., CP, NDF, ADF, starch, ash, Ca, and $\mathrm{P}$ ) was calculated by using the analyzed chemical composition of the individual feed ingredients and their inclusion rate in the TMR (Table 1). Concentration of RDP, RUP, $\mathrm{NE}_{\mathrm{L}}$, and $\mathrm{NFC}$ and $\mathrm{NE}_{\mathrm{L}}$ balance were estimated based on NRC (2001) using average DMI, milk yield, milk composition, and BW of the cows during the experiment.

During the enteric gas measurement week in both study phases, 2 samples of each treatment TMR, including the basal TMR without added premix, were collected and kept frozen at $-20^{\circ} \mathrm{C}$. These samples were composited by treatment and sent for analysis of 3-NOP concentration (DSM Nutritional Products, Global R\&D Analytics, Kaiseraugst, Switzerland).

Enteric Gas Emissions. Enteric gaseous emissions $\left(\mathrm{CH}_{4}, \mathrm{CO}_{2}\right.$, and $\left.\mathrm{H}_{2}\right)$ were measured, in each experimental phase, during the last $3 \mathrm{~d}$ of the covariate period and in the last $3 \mathrm{~d}$ of the treatment period using the GreenFeed system (C-Lock Inc., Rapid City, SD). Measurements were conducted following the procedures recommended by Hristov et al. (2015a,b). Briefly, during each measurement period, spot gas emission data were collected over $3 \mathrm{~d}$ as follows: starting at 0900, 1500, and $2100 \mathrm{~h} \mathrm{(d} \mathrm{1),} \mathrm{0300,} \mathrm{1200,} \mathrm{and} 1700 \mathrm{~h} \mathrm{(d} \mathrm{2),} \mathrm{and} 0000$
Table 1. Ingredient and chemical composition of the basal diet fed during the experiment

\begin{tabular}{|c|c|}
\hline Item & $\operatorname{Diet}^{1}$ \\
\hline \multicolumn{2}{|l|}{ Feed ingredient, $\%$ of diet DM } \\
\hline Corn silage ${ }^{2}$ & 50.0 \\
\hline Alfalfa haylage $^{3}$ & 10.0 \\
\hline Ground corn grain ${ }^{4}$ & 10.0 \\
\hline Soybean seeds, roasted ${ }^{5}$ & 7.0 \\
\hline Canola meal ${ }^{6}$ & 8.0 \\
\hline Cottonseed, whole ${ }^{7}$ & 6.0 \\
\hline SoyPlus $^{8}$ & 4.0 \\
\hline Molasses $^{9}$ & 3.0 \\
\hline Mineral and vitamin premix ${ }^{10}$ & 2.0 \\
\hline \multicolumn{2}{|c|}{ Composition, ${ }^{11} \%$ of DM (or as indicated) } \\
\hline $\mathrm{CP}^{11}$ & 16.5 \\
\hline $\mathrm{RDP}^{12}$ & 10.3 \\
\hline $\mathrm{RUP}^{12}$ & 6.2 \\
\hline $\mathrm{NDF}^{11}$ & 31.8 \\
\hline $\mathrm{ADF}^{11}$ & 21.3 \\
\hline Starch & 24.3 \\
\hline Ether extract & 5.8 \\
\hline $\mathrm{NE}_{\mathrm{L}},{ }^{11} \mathrm{Mcal} / \mathrm{kg}$ & 1.62 \\
\hline Average $\mathrm{NE}_{\mathrm{L}}$ balance ${ }^{13} \mathrm{Mcal} / \mathrm{d}$ & 0.70 \\
\hline Average MP balance, ${ }^{13} \mathrm{~g} / \mathrm{d}$ & 89.0 \\
\hline $\mathrm{NFC}^{12}$ & 42.3 \\
\hline Ash & 5.92 \\
\hline $\mathrm{Ca}^{11}$ & 0.70 \\
\hline $\mathrm{P}^{11}$ & 0.40 \\
\hline
\end{tabular}

${ }^{1}$ Average diet composition for covariate and treatment phases 1 and 2.

${ }^{2}$ Corn silage was $37.8 \% \mathrm{DM}$ and contained (DM basis) $7.9 \% \mathrm{CP}, 40.2 \%$ $\mathrm{NDF}$, and $31.7 \%$ starch.

${ }^{3}$ Haylage was $33.1 \%$ DM and contained (DM basis) $20.1 \% \mathrm{CP}$ and $42.7 \%$ NDF.

${ }^{4}$ Ground corn grain contained (DM basis) $7.7 \% \mathrm{CP}$.

${ }^{5}$ Soybean seeds, roasted, contained (DM basis) $37.4 \% \mathrm{CP}$.

${ }^{6}$ Canola meal contained (DM basis) $42.4 \% \mathrm{CP}$.

${ }^{7}$ Cottonseed contained (DM basis) $23.4 \% \mathrm{CP}$.

${ }^{8}$ SoyPlus (Landus Cooperative, Ames, IA) contained (DM basis) $46.6 \% \mathrm{CP}$

${ }^{9}$ Molasses (Westway Feed Products, Tomball, TX) contained (DM basis) $3.9 \% \mathrm{CP}$ and $66 \%$ total sugar.

${ }^{10}$ The premix (Cargill Animal Nutrition, Cargill Inc., Roaring Spring, $\mathrm{PA})$ contained $(\%$, as-is basis) trace mineral mix, $0.86 ; \mathrm{MgO}(56 \%$ $\mathrm{Mg}$ ), 8.0; NaCl, 6.4; vitamin ADE premix (Cargill Animal Nutrition, Cargill Inc.), 0.48; limestone, 37.2; selenium premix (Cargill Animal Nutrition, Cargill Inc.), 0.07; and dry corn distillers grains with solubles, 46.7. Ca, $14.1 \%$; P, 0.39\%; Mg, 4.59\%; K, 0.44\%; S, 0.39\%; Se, $6.91 \mathrm{mg} / \mathrm{kg}$; Cu, $362 \mathrm{mg} / \mathrm{kg}$; Zn, 1,085 mg/kg; Fe, $186 \mathrm{mg} / \mathrm{kg}$; vitamin A, 276,717 IU/kg; vitamin D, 75,000 IU/kg; and vitamin E, 1,983 IU/ $\mathrm{kg}$.

${ }^{11}$ Values calculated using the chemical analysis (Cumberland Valley Analytical Services Inc., Waynesboro, PA) of the feed ingredients and their inclusion in the diets.

${ }^{12}$ Estimated based on NRC (2001).

${ }^{13}$ Estimated (total required minus total supply) based on NRC (2001) using actual DMI, milk yield, milk composition, and BW of the cows throughout the experiment.

and $0500 \mathrm{~h}(\mathrm{~d} 3)$ to obtain a representative sample of a 24-h feeding cycle. A pelletized cattle feed (Stoker Grower 14, Purina Animal Nutrition LLC, Shoreview, MN) was used as bait feed and was offered at each sampling event for a total of $4,000 \mathrm{~g} /$ cow over $3 \mathrm{~d}$, and the amount was included in the DMI value during the 
gas sampling week. Two GreenFeed units were used and all cows were sampled in less than $2 \mathrm{~h}$. Individual breath gas samples were collected for 5 min followed by a 2-min background sample collection. The GreenFeed system is equipped with a head position sensor and gas emission data are rejected when the cow's head position criteria are not met. Each GreenFeed unit was calibrated following the manufacturer's recommendations. Enteric $\mathrm{CH}_{4}$ emission yield (g/kg of DMI) and intensity $(\mathrm{g} / \mathrm{kg}$ of milk yield or $\mathrm{g} / \mathrm{kg}$ of ECM) were calculated based on the daily $\mathrm{CH}_{4}$ emissions and DMI and ECM yield data during the gas measurement periods.

Milk Production, Composition, and $B W$. Milk production of the cows was recorded daily at each milking. Milk samples were collected from 2 consecutive milkings (p.m. and a.m.) during the last day of the covariate and the last day of the treatment periods (phase 1 and 2). An aliquot of each milk sample was placed in tubes with a preservative (2-bromo-2-nitropropane-1,3diol) and submitted to Dairy One Cooperative Inc. (Ithaca, NY) for analysis of milk fat, true protein, lactose, SCC, and MUN using Milkoscan models 6000, FT+ and Fossomatic models 5000 of FC (Foss Electric A/S, Hillerød, Denmark). Milk composition data were weighted for the corresponding milk yield during each milk sampling event. An aliquot of the milk samples collected during the treatment periods was placed in tubes without preservative and stored at $-20^{\circ} \mathrm{C}$ until analyzed for milk fatty acid composition as described in Rico and Harvatine (2013). Cow BW was recorded twice daily upon exiting the milking parlor using an AfiFarm 3.04E scale system (S.A.E. Afikim, Rehovot, Israel).

\section{Statistical Analysis}

All data were analyzed using the MIXED procedure of SAS, version 9.4 (SAS Institute Inc., Cary, NC). Data were tested for normality using the UNIVARIATE procedure of SAS. Statistical analysis of SCC was performed on log-transformed data. The statistical model included treatment, phase (phases 1 and 2), treatment $\times$ study phase interaction, and covariate response (for DMI, milk yield and composition, BW, and enteric $\mathrm{CH}_{4}$ emission data). The effect of treatment $\times$ study phase was nonsignificant $(P \geq 0.05)$ for any of the variables studied and was removed from the final model. Block and block $\times$ treatment were random effects and all others were considered fixed effects. Enteric gas emission data $\left(\mathrm{CH}_{4}, \mathrm{CO}_{2}\right.$, and $\mathrm{H}_{2}, \mathrm{~g} / \mathrm{d}$ per animal) were averaged by cow for the covariate and treatment periods and the average values were used in the statistical analysis. Feed DMI, milk yield, BW, and estimated feed efficiency data were averaged during the gas sampling week and the average values were used in the statistical analysis. The average milk yield and DMI during milk sampling weeks (i.e., last $7 \mathrm{~d}$ of the covariate or treatment periods) were used to calculate milk fat, true protein, lactose, and ECM yields; ECM was calculated according to Sjaunja et al. (1990): ECM $(\mathrm{kg} / \mathrm{d})=\mathrm{kg}$ of milk $\times[(38.3 \times \%$ fat $\times 10+24.2 \times \%$ true protein $\times 10+16.54 \times \%$ lactose $\times 10+20.7) \div$ $3,140]$. Average DMI and milk and ECM yields during the gas sampling week were used to estimate $\mathrm{CH}_{4}$ and $\mathrm{CO}_{2}$ yield (i.e., g per $\mathrm{kg}$ of $\mathrm{DMI}$ ) and intensity (i.e., g per $\mathrm{kg}$ of milk or ECM). Body weight change was calculated as the difference between average BW during the last week of each treatment period and the average BW during the last week of the respective covariate period. Data were analyzed using orthogonal and polynomial contrasts to evaluate 3-NOP treatments versus control and evaluate for linear and quadratic effects of 3-NOP. The IML procedure of SAS with the ORPOL function was used to derive contrast coefficients. All data, except milk fatty acid composition, are presented as covariate-adjusted least squares means. Statistical differences were considered significant at $P \leq 0.05$ and a trend at $0.05<P \leq 0.10$. Differences at $0.10<P \leq$ 0.15 were considered numerical trends.

\section{RESULTS AND DISCUSSION}

Dose levels for this study were selected based on previous research with 3 -NOP in our laboratory (i.e., the Hristov et al., 2015a). In addition, we wanted to test higher doses, comparable to studies conducted with beef cattle (Romero-Pérez et al., 2014, 2015; Vyas et al., 2016) to determine maximum response to 3-NOP.

Measured concentration of 3 -NOP in the treatment TMR were $0,37,55,73,92,137$, and $183 \mathrm{mg} / \mathrm{kg}$ feed DM for control, 40NOP, 60NOP, 80NOP, 100NOP, 150NOP, and 200NOP, respectively. Relative standard deviation was calculated and results were below $10 \%$ for each 3-NOP level set of samples.

Compared with the control (Table 2), the decrease $(P<0.001)$ in daily enteric $\mathrm{CH}_{4}$ emissions by $3-\mathrm{NOP}$ ranged from 22 to $40 \%$ (overall average of $31 \%$ ). Expressed in relation to DMI, the decrease $(P<0.001)$ in $\mathrm{CH}_{4}$ emission yield by 3-NOP ranged from 16 to $36 \%$ (overall average of 26\%), and expressed on an ECM basis, the decrease $(P<0.001)$ in $\mathrm{CH}_{4}$ emission intensity ranged from 25 to $45 \%$ (overall average was $33 \%$ ). Daily $\mathrm{CH}_{4}$ emissions, emission yield, and intensity were lower $(P \leq 0.03)$ than the control for each targeted 3 -NOP inclusion rate, except emission yield tended to be lower than the control for $60 \mathrm{NOP}$ and $80 \mathrm{NOP}(P=$ 0.06 and 0.10, respectively; data not shown in Table 2). Numerically, maximum mitigation effect was achieved 
with $150 \mathrm{NOP}$, but no statistical difference was observed in daily $\mathrm{CH}_{4}$ emissions $(P \geq 0.93), \mathrm{CH}_{4}$ emission yield $(P \geq 0.67)$, and intensity $(P \geq 0.33)$ among $100 \mathrm{NOP}$, $150 \mathrm{NOP}$, and $200 \mathrm{NOP}$ treatments. Further, $\mathrm{CH}_{4}$ emission yield for 40NOP was not different $(P \geq 0.75)$ from $60 \mathrm{NOP}$ and $80 \mathrm{NOP}$ and that for $100 \mathrm{NOP}$ was not different $(P \geq 0.84)$ from $150 \mathrm{NOP}$ and $200 \mathrm{NOP}$ (data not shown in Table 2). Based on these results, it can be concluded that maximum mitigation effect of 3 -NOP was achieved with 150 NOP but no statistical difference was observed among the 3 highest doses. A summary of all experiments conducted in our laboratory (Figure 1) shows an average $\mathrm{CH}_{4}$ yield mitigation effect of 3-NOP of $-27.2 \%$ with about a 10 percentage-unit improvement in reduction with doses higher than $60 \mathrm{mg} / \mathrm{kg}$. It is noted that of the 2 studies in which $80 \mathrm{mg} / \mathrm{kg} 3-\mathrm{NOP}$ was used, one (current experiment) appears to be an outlier $(-15.9 \%$ reduction vs. $-29.1 \%$ in Hristov et al., 2015a) and also data for the highest doses $(\geq 100 \mathrm{mg} /$ $\mathrm{kg}$ ) are from a single (current) study.

The pattern in daily enteric $\mathrm{CH}_{4}$ emissions over a 24-h feeding cycle in the current study is shown in Figure 2. Across 3-NOP application rates and sampling time, the highest $\mathrm{CH}_{4}$ mitigation effect ( $46 \%$ decrease with 100NOP) was $2 \mathrm{~h}$ after feeding fresh TMR and the lowest $(12 \%$ decrease with $40 \mathrm{NOP})$ was at $21 \mathrm{~h}$ after feeding. These results are consistent with a report from a recent long-term study from our laboratory under similar feeding conditions, in which the mitigation effect of 3-NOP fed at $60 \mathrm{mg} / \mathrm{kg}$ DM basis was the lowest (5\%) $2 \mathrm{~h}$ before feeding and the highest (45\%) within 6 $\mathrm{h}$ after feeding (Hristov and Melgar, 2019).

In beef cattle fed high-forage or high-grain diets, a dose-related $\mathrm{CH}_{4}$ mitigation effect of 3 -NOP was reported by Vyas et al. (2016). In that study, only the 2 highest 3-NOP inclusion levels (150 and $200 \mathrm{mg} / \mathrm{kg}$ feed $\mathrm{DM}$ ) were statistically different from the control when expressed as daily $\mathrm{CH}_{4}$ emissions. However, when expressed as emission yield, 3-NOP was most effective at $100 \mathrm{mg} / \mathrm{kg}$ feed DM (Vyas et al., 2016).

Previous studies in our laboratory (Hristov et al., 2015a; Lopes et al., 2016; Melgar et al., 2019) have shown that the inhibitory effect of 3 -NOP on enteric $\mathrm{CH}_{4}$ emissions in mid- to late-lactation cows persisted over the duration of the experiment, did not decrease overall emissions of $\mathrm{CO}_{2}$, and was accompanied by increased $\mathrm{H}_{2}$ emissions. Although it is expected than enteric $\mathrm{CO}_{2}$ emissions will increase under $\mathrm{CH}_{4}$ inhibition, $\mathrm{CO}_{2}$ responses to 3 -NOP have been inconsistent. In the current study, daily $\mathrm{CO}_{2}$ emissions were unaffected by 3-NOP, but when expressed per unit of DMI or milk/ ECM yield, tended to linearly increase with 3-NOP dose. In contrast, Melgar et al. (2020) reported a 5\% decrease in daily $\mathrm{CO}_{2}$ emissions in 3 -NOP-fed early- lactation cows. This was explained with the slightly lower DMI of the 3-NOP cows compared with control cows. Carbon dioxide emission yield, however, was not affected by 3-NOP in the Melgar et al. (2020) study.

Hydrogen emissions were quadratically increased $(P$ $=0.005)$ by $3-\mathrm{NOP}$ in the current study. The highest $\mathrm{H}_{2}$ emissions were associated with the lowest $\mathrm{CH}_{4}$ emissions with $150 \mathrm{NOP}$ treatment. Inhibition of methanogenesis causes accumulation of $\mathrm{H}_{2}$ (Trei et al., 1972) in the liquid and gas phases of ruminal contents (Hungate, 1967; Janssen, 2010; Wang et al., 2014). Hydrogen gaseous emissions and dissolved $\mathrm{H}_{2}$ concentration in ruminal fluid, when methanogenesis is inhibited by 3 -NOP, are also affected by fermentation pattern and molar proportion of the major VFA (Reynolds et al., 2014; Lopes et al., 2016; Melgar et al., 2020). Similar increases in $\mathrm{H}_{2}$ emissions have been observed using various enteric $\mathrm{CH}_{4}$ inhibitors (Trei et al., 1972; Demeyer and Van Nevel, 1975; Russell and Martin, 1984).

Limitations of the current experiment include relatively small number of animals per treatment and short duration of the study. Nevertheless, findings were generally consistent with those of previous experiments with 3-NOP (Hristov et al., 2015a; Melgar et al., 2019, 2020; see also Figure 1). Overall, DMI was not different between 3-NOP and the control in the current study but increasing 3-NOP dose tended to linearly decrease $(P=0.07)$ DMI by $6 \%$ with the higher doses. Some studies reported a decrease in DMI with the inclusion of 3-NOP in beef and dairy cattle (Vyas et al., 2018; Melgar et al., 2020). In the Vyas et al. (2018) study, beef steers receiving 200 and $125 \mathrm{mg}$ of $3-\mathrm{NOP} / \mathrm{kg}$ feed DM decreased their DMI by 7 and $5 \%$ during the backgrounding and finishing phase, respectively. In the Melgar et al. (2020) study, which was with cows in 3 to $112 \mathrm{DIM}$, the effect of feeding $60 \mathrm{mg}$ of $3-\mathrm{NOP} / \mathrm{kg}$ of feed DM on DMI was attributed to the lower BW of the 3 -NOP cows at the beginning of the experiment (DMI was not different from control when expressed on a BW basis). Other studies with dairy cows (Hristov et al., 2015a; Melgar et al., 2019; Van Wesemael et al., 2019) demonstrated that the mitigation effect of 3-NOP was not associated with negative effects on DMI, milk yield, and BW. In another short-term experiment, Melgar et al. (2018) supplemented up to $120 \mathrm{mg} 3-\mathrm{NOP} / \mathrm{kg}$ feed DM to dairy cows and reported no effect of 3-NOP on TMR palatability and DMI. Compared with the control, 3-NOP did not affect ECM yield but linearly increased $(P=0.004)$ ECM feed efficiency.

Inclusion of $3-\mathrm{NOP}$ in the basal diet did not affect milk yield or milk composition of the cows in the current experiment (Table 3), except it increased milk fat concentration and yield $(P \leq 0.01)$. A trend for a linear decrease $(P=0.10)$ in milk yield was observed with 
Melgar et al.: 3-NITROOXYPROPANOL IN DAIRY COWS

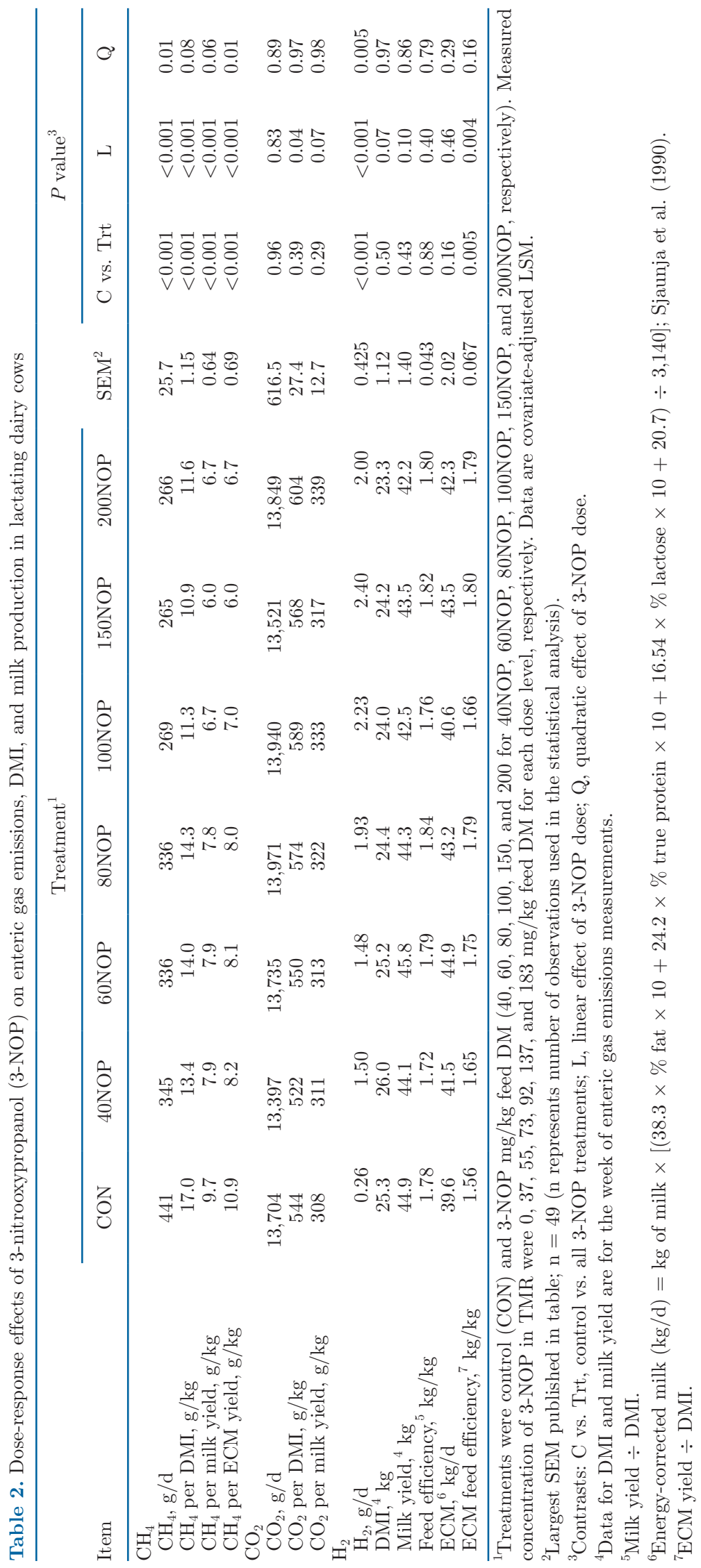


increasing 3-NOP dose, but ECM yield was not affected by treatment. The observed lack of effect of 3-NOP on lactational performance in the current study is consistent with both long-term production studies (Hristov et al., 2015a; Melgar et al., 2019, 2020; Van Wesemael et al., 2019) as well as short-term experiments (Haisan et al., 2014; Reynolds et al., 2014; Lopes et al., 2016; Haisan et al., 2017). In the current study, increasing the dose of 3 -NOP linearly increased $(P \leq 0.004)$ milk fat concentration and milk fat yield. Similarly, milk fat concentration and yield were increased in a recent study with mid-lactation cows (Melgar et al., 2019). In contrast, Hristov et al. (2015a) did not report changes in milk fat concentration and yield with 3-NOP supplemented at 40,60, and $80 \mathrm{mg} / \mathrm{kg}$ feed DM. Compared with control, 3-NOP did not affect milk true protein and lactose concentration, or milk true protein and milk lactose yield. Concentration of MUN was linearly increased $(P=0.005)$ by $3-\mathrm{NOP}$ dose. The increased
MUN in cows receiving 3-NOP is consistent with previously reported data in long-term, randomized block design experiments with early-lactation (Melgar et al., 2020) and mid-lactation cows (Melgar et al., 2019). Others, however, have reported no effect of 3-NOP on MUN in dairy cows (Reynolds et al., 2014; Haisan et al., 2017). In the Melgar et al. (2020) study, the observed increase in MUN could be partially explained by the increased CP digestibility by 3-NOP. Melgar et al. (2020) also reported a decrease in plasma concentration of some essential (e.g., Arg) and nonessential (e.g., Cit) AA with 3-NOP, which could have contributed to the effect of 3-NOP on MUN in that study and suggests that hepatic oxidation of AA could be a significant source of MUN (Nousiainen et al., 2004). Digestibility and urinary $\mathrm{N}$ excretion or plasma AA data were not collected in the current experiment.

Body weight and BW change of the cows were not affected by $3-\mathrm{NOP}$ in the current experiment. The ef-

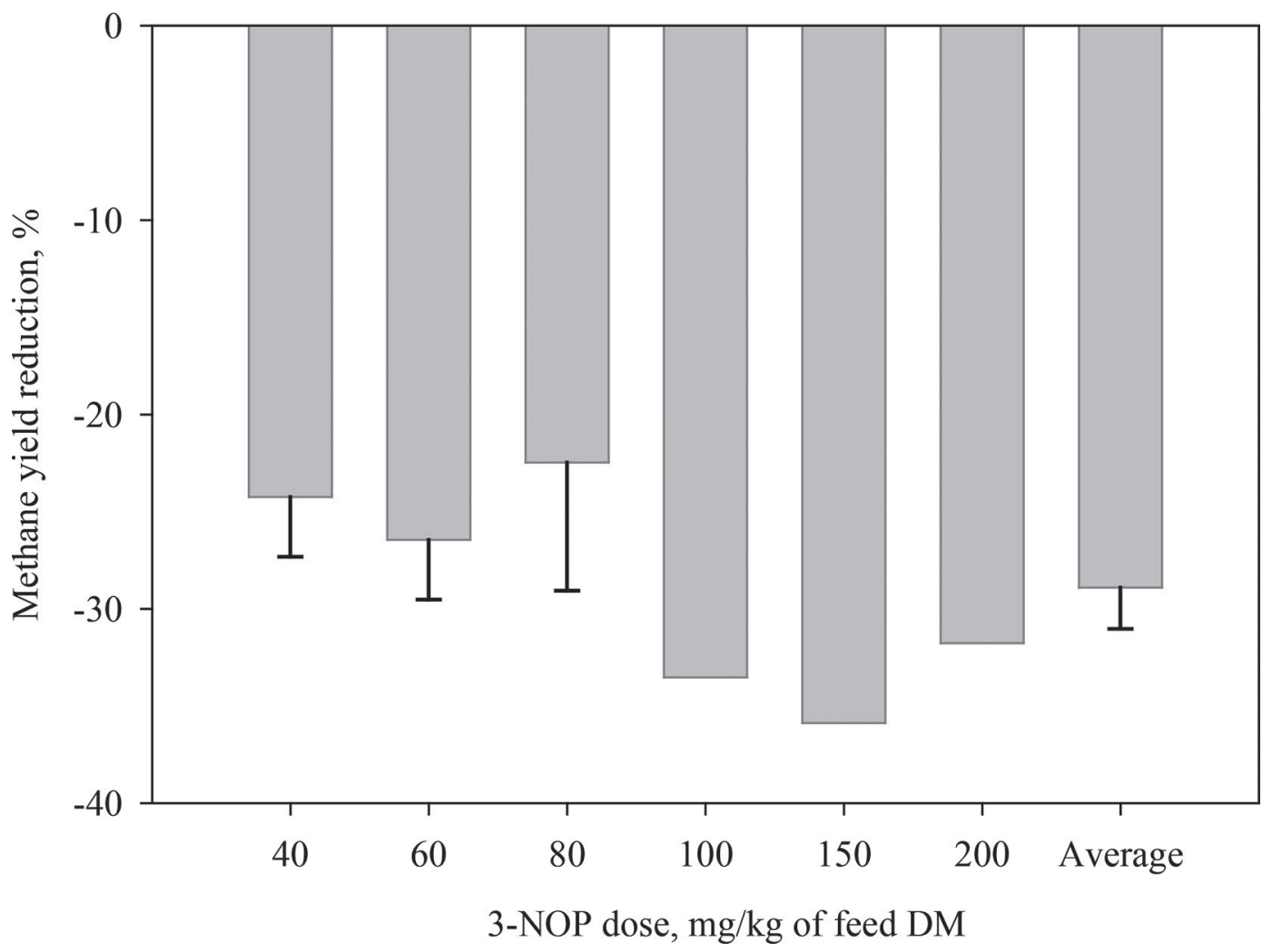

Figure 1. Average methane mitigation effect of dietary supplementation with 3-nitrooxypropanol (3-NOP) in dairy cows. Inclusion doses were control and 3-NOP included at 40,60, 80, 100, 150, and $200 \mathrm{mg} / \mathrm{kg}$ of feed DM, and mitigation effects were $-24.3,-26.5,-22.5,-33.5$, -35.9 , and $-31.8 \%$ for $40,60,80,100,150$, and $200 \mathrm{mg} / \mathrm{kg}$ of 3 -NOP, respectively. Enteric methane emissions were measured using the GreenFeed system (C-Lock Inc., Rapid City, SD). Data are average methane yield ( $\mathrm{g}$ of $\mathrm{CH}_{4} / \mathrm{kg}$ of DMI) reduction, compared with a control, and error bars represent SEM (data for 100, 150, and $200 \mathrm{mg} / \mathrm{kg} 3-\mathrm{NOP}$ are from a single experiment, and therefore no error bars are associated with these doses); $\mathrm{n}=236$ for 40 and $80 \mathrm{mg} / \mathrm{kg}$ (187 individual cow observations from Hristov et al., 2015a; and 49 from the current study), $\mathrm{n}$ = 649 for $60 \mathrm{mg} / \mathrm{kg}$ (187 observations from Hristov et al., 2015a; 61 from Lopes et al., 2016; 160 from Melgar et al., 2019; 192 from Melgar et al., 2020; and 49 from the current study), $\mathrm{n}=49$ for 100, 150, and $200 \mathrm{mg} / \mathrm{kg}$ from the current study (n represents the number of observations used in the statistical analysis in each experiment). 


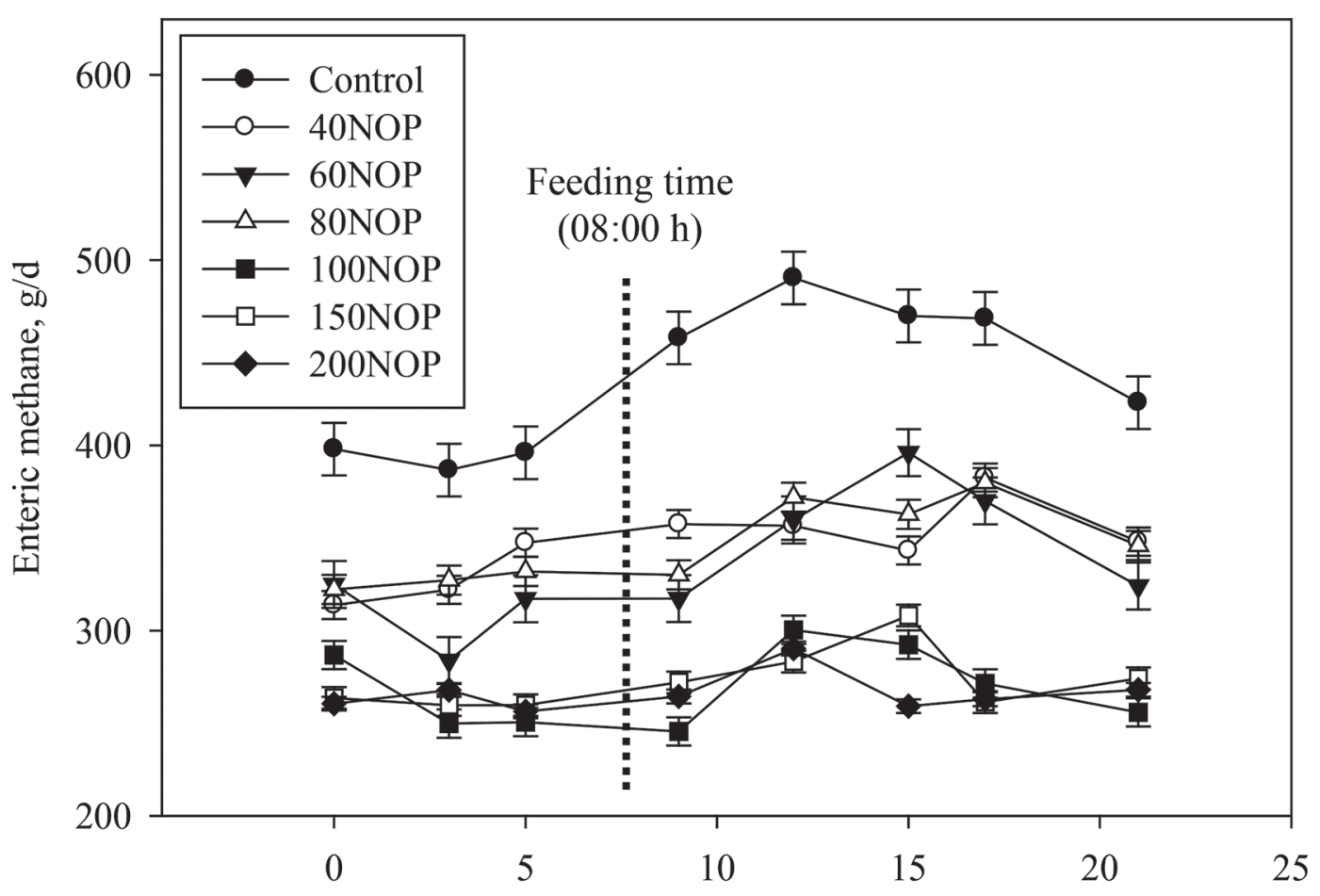

Time of day, $\mathrm{h}$

Figure 2. Diurnal pattern in enteric methane emissions of lactating dairy cows fed 3-nitrooxypropanol (3-NOP). Treatments were control and $3-\mathrm{NOP} \mathrm{mg} / \mathrm{kg}$ of feed DM (40,60, 80, 100, 150, and 200; 40NOP, 60NOP, 80NOP, 100NOP, 150NOP, and 200NOP, respectively). Methane emissions were measured using the GreenFeed system (C-Lock Inc., Rapid City, SD). Data are treatment covariate-adjusted LSM and bars represent SE; $\mathrm{n}=7$ (number of independent data points for each mean value). Main effect of treatment $(P<0.001$ ). Treatment $\times$ study phase interaction, $P=0.32$. The average decrease $(P \leq 0.03)$, across 3 -NOP application rates, compared with the control for each measurement time point (see Materials and Methods) was 26, 26, 26, 35, 33, 30, 31, and 28\% for 0000, 0300, 0500, 0900, 1200, 1500, 1700, and 2100 h, respectively.

fect of 3-NOP on BW appeared to differ between beef (Romero-Pérez et al., 2015; Martinez-Fernandez et al., 2018; Vyas et al., 2018) and dairy cattle (Haisan et al., 2014; Hristov et al., 2015a; Melgar et al., 2019, 2020), but the current short-term experiment was not designed to elucidate effects of 3-NOP on BW.

Inclusion dose of 3-NOP quadratically increased $(P$ $=0.02$ ) the sum of de novo synthesized fatty acids in milk (Table 4). In contrast, no effects on milk fatty acids profile was reported by Reynolds et al. (2014) when 3-NOP was dosed directly into the rumen where they observed a transient $\mathrm{CH}_{4}$ inhibition effect. In dairy cows, $50 \%$ of milk fatty acids are formed from de novo synthesis in the mammary gland (Bauman and Davis, 1974). Thus, the increase in milk fat concentration and yield observed in the current experiment and in Melgar et al. (2019) likely resulted from a shift in rumen fermentation toward increased production of short-chain milk fatty acids precursors, such as butyrate (Black et al., 1961; Ellis et al., 2008; Dijkstra et al., 2011). If rumen VFA absorption rate is not affected by treatment, it is expected that VFA concentrations would be approximately representative of VFA production rates (Sutton et al., 2003). Several studies had reported increased molar proportion of butyrate in rumen fluid of dairy cows fed 3-NOP (Lopes et al., 2016; Haisan et al., 2017; Melgar et al., 2020). Although Melgar et al. (2020) did not report an effect of 3-NOP inclusion on molar proportion of propionate in early-lactation cows, it is important to indicate that in line with the theory of changes in fermentation pattern when methanogenesis is inhibited (Wolin, 1960; Marty and Demeyer, 1973), an increase in propionate was observed by Haisan et al. (2014), Romero-Pérez et al. (2015), and Lopes et al. (2016) in studies with beef or dairy cattle fed 3-NOP.

In the current study, increasing 3 -NOP dose decreased linearly $(P=0.002)$ the sum of trans fatty acids, particularly trans-18:1 isomers, in milk fat. Based on milk fatty acid composition in the current experiment, it appeared that rumen biohydrogenation was following the normal pathways (Bauman and Griinari, 2003). The increased $(P=0.03)$ concentration of SFA and the tendency for decreased $(P=0.07)$ MUFA (and to a lesser extent PUFA, $P=0.12)$ in milk fat observed 


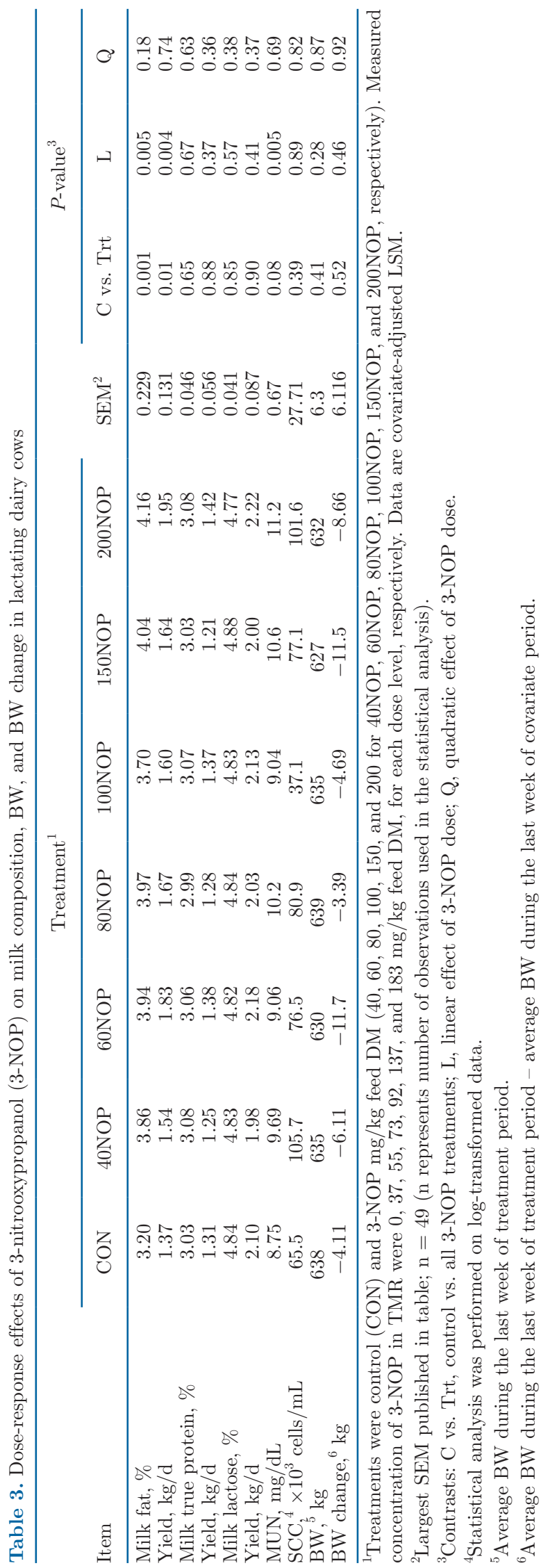

in the current study and also reported by Hristov et al. (2015a) suggest that rumen biohydrogenation may have provided an additional, although minor (Nagaraja et al., 1997), sink for $\mathrm{H}_{2}$ in cows fed 3-NOP. Although data are not conclusive, our results suggest that rumen biohydrogenation may be enhanced by 3 -NOP. According to Lourenço et al. (2010), biohydrogenation is not necessarily stimulated by availability of $\mathrm{H}_{2}$ itself but may have been affected through other $\mathrm{H}_{2}$-utilization processes.

Compared with control, sum of C16 fatty acids remained unchanged by 3 -NOP, whereas concentration of the sum of preformed $(>\mathrm{C} 16)$ fatty acids in milk fat tended to decrease $(P=0.08)$ with 3 -NOP inclusion. The sum of odd-and branched-chain fatty acids tended $(P=0.08)$ to generally increase with 3 -NOP dose. Changes in the concentrations of trans fatty acids can be explained by changes in microbial processes in the rumen that induce a shift in the molar proportions of VFA toward decreasing acetate and increasing propionate (Van Soest, 1963; Bauman and Griinari, 2003). A decrease in the molar proportion of acetate is commonly observed in 3-NOP-fed cows (Reynolds et al., 2014; Haisan et al., 2014; Lopes et al., 2016) and can be related to $\mathrm{H}_{2}$ accumulation due to the inhibition of $\mathrm{CH}_{4}$ synthesis (van Lingen et al., 2016). Melgar et al. (2020) showed that inclusion of 3-NOP decreased rumen acetate molar proportion and did not affect propionate molar proportion, but increased butyrate and valerate molar proportions of total VFA in ruminal fluid.

We can determine by calculation that the decrease in daily enteric $\mathrm{CH}_{4}$ emissions (by 96 to $176 \mathrm{~g} / \mathrm{d}$ of $\mathrm{CH}_{4}$ ) would have increased the availability of feed digestible energy from 1.25 to $2.29 \mathrm{Mcal} / \mathrm{d}$. If energy in $\mathrm{CH}_{4}$ synthesized in the rumen is converted to $\mathrm{NE}_{\mathrm{L}}$ with efficiency similar to that of dietary digestible energy (NRC, 1981), and we assume no differences in efficiency of energy use between treatments (and no change in $\mathrm{BW}$ ), the reduction in emitted $\mathrm{CH}_{4}$ with 3 -NOP would represent, in theory, an additional (over the control) $0.40,0.44,0.43,0.74,0.72$, and $0.71 \mathrm{Mcal} / \mathrm{d} \mathrm{NE}_{\mathrm{L}}$ for 40NOP, 60NOP, 80NOP, 100NOP, 150NOP, and $200 \mathrm{NOP}$, respectively, that could potentially be used for productive purposes. Previous studies in mid- to late-lactation cows reported from 0.26 (Hristov et al., 2015a) to 0.34 (Melgar et al., 2019) Mcal/cow $\mathrm{NE}_{\mathrm{L}}$ per day digestible energy gain as a result of the reduction of emitted enteric $\mathrm{CH}_{4}$ with the inclusion of 3-NOP at $60 \mathrm{mg} / \mathrm{kg}$ feed DM. In an early-lactation study, when maintenance and milk production requirements exceed the available energy from feed intake, Melgar et al. (2020) reported a potential increase in $\mathrm{NE}_{\mathrm{L}}$ availability of $0.29 \mathrm{Mcal} / \mathrm{d}$ in 3-NOP-fed cows, which could support an additional milk yield of $0.39 \mathrm{~kg} / \mathrm{d}$. In the 
Melgar et al.: 3-NITROOXYPROPANOL IN DAIRY COWS

6154

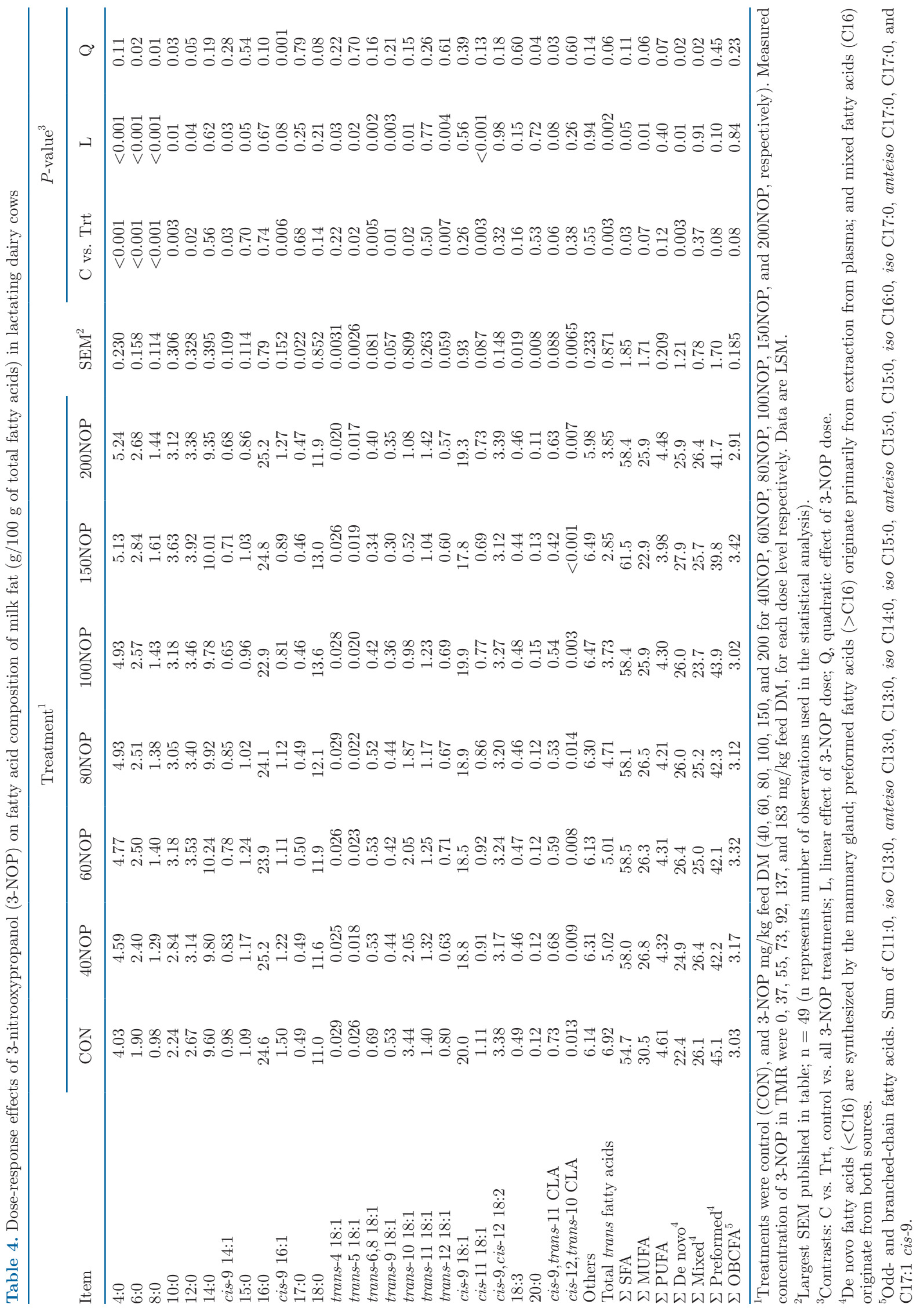


current experiment, however, the spared $\mathrm{CH}_{4}$ energy was most likely used for milk fat synthesis and lactose/ milk volume were not affected by treatment, and in fact, a trend for decreased milk volume by 3 -NOP was observed, which was a result of the trend for decreased DMI (as feed efficiency was not affected by treatment).

\section{CONCLUSIONS}

Administration of $3-\mathrm{NOP}$ via the TMR at a target concentration of 0 to $200 \mathrm{mg} / \mathrm{kg}$ feed DM quadratically decreased daily enteric $\mathrm{CH}_{4}$ emissions from 22 to $40 \%$, with an average reduction of $31 \%$. Similar effects were observed for $\mathrm{CH}_{4}$ emission yield and intensity with average reduction by 26 and $33 \%$, respectively. Maximum mitigation effect of 3-NOP was achieved with $150 \mathrm{mg} /$ $\mathrm{kg}$ feed DM, but no statistical difference was observed among the 3 highest doses (100, 150, and $200 \mathrm{mg} / \mathrm{kg}$ ). Within the 3-NOP doses studied, the average reduction in $\mathrm{CH}_{4}$ was $26 \%$ when expressed as $\mathrm{g} / \mathrm{kg}$ of feed $\mathrm{DM}$ consumed and $33 \%$ when expressed in $\mathrm{g} / \mathrm{kg}$ ECM yield. In the conditions of this short-term experiment, 3-NOP did not affect DMI and milk yield of the cows, but overall, treatment linearly increased milk fat concentration and yield and increased ECM feed efficiency. Concentrations of de novo synthesized fatty acids in milk fat were also increased by 3-NOP, suggesting increased energy availability with 3-NOP, compared with the control. These results suggest that 3 -NOP is a promising feed additive for reducing enteric $\mathrm{CH}_{4}$ emissions, while maintaining lactational performance in dairy cows and potentially increasing milk fat yield.

\section{ACKNOWLEDGMENTS}

This work was supported by the USDA National Institute of Food and Agriculture Federal Appropriations under Project PEN 04539 and accession number 1000803. The authors thank DSM Nutritional Products (Basel, Switzerland) for providing partial financial support for the project. The authors also thank the staff of The Pennsylvania State University's Dairy Teaching and Research Center (University Park, PA) for their conscientious care and management of the animals and for technical assistance during the study. A. Melgar was supported by the Government of Panama through the Institute for Training and Development of Human Resources-National Secretariat for Science, Technology and Innovation (IFARHU-SENACYT; Calle Luis Bonilla 206, Clayton, City of Knowledge, Panama) Scholarship Program and the Agricultural Research Institute of Panama (IDIAP, Calle Carlos Lara 157, Clayton, City of Knowledge, Panama). The authors have not stated any conflicts of interest.

\section{REFERENCES}

AOAC International. 2000. Official Methods of Analysis. 17th ed. AOAC International, Arlington, VA.

AOAC International. 2006. Official Methods of Analysis. 18th ed. AOAC International, Arlington, VA.

Bauman, D. E., and C. L. Davis. 1974. Biosynthesis of milk fat. Pages 31-75 in Lactation: A Comprehensive Treatise, Vol. 2. B. L. Larson and V. R. Smith, ed. Academic Press, New York, NY.

Bauman, D. E., and J. M. Griinari. 2003. Nutritional regulation of milk fat synthesis. Annu. Rev. Nutr. 23:203-227. https://doi.org/ 10.1146/annurev.nutr.23.011702.073408.

Black, A. L., M. Kleiber, and A. M. Brown. 1961. Butyrate metabolism in the lactating cow. J. Biol. Chem. 236:2399-2403.

CVAS (Cumberland Valley Analytical Services). 2018. Resources-Lab Procedures. Accessed Oct. 16, 2018. http://www.foragelab.com/ Resources/Lab-Procedures/.

Demeyer, D. I., and C. J. Van Nevel. 1975. Methanogenesis, an integrated part of carbohydrate fermentation and its control. Pages 366-382 in Digestion and Metabolism in the Ruminant. I. W. McDonald and A. C. I. Warner, ed. University of New England Publishing Unit, Armidale, Australia.

Dijkstra, J., A. Bannink, J. France, E. Kebreab, and S. van Gastelen. 2018. Short communication: Antimethanogenic effects of 3-nitrooxypropanol depend on supplementation dose, dietary fiber content, and cattle type. J. Dairy Sci. 101:9041-9047. https://doi.org/ $10.3168 / j d s .2018-14456$.

Dijkstra, J., S. M. van Zijderveld, J. A. Apajalahti, A. Bannink, W. J. J. Gerrits, J. R. Newbold, H. B. Perdok, and H. Berends. 2011. Relationships between methane production and milk fatty acid profiles in dairy cattle. Anim. Feed Sci. Technol. 166-167:590-595. https://doi.org/10.1016/j.anifeedsci.2011.04.042.

Duin, E. C., T. Wagner, S. Shima, D. Prakash, B. Cronin, D. R Yáñez-Ruiz, S. Duval, R. Rümbeli, R. T. Stemmler, R. K. Thauer, and M. Kindermann. 2016. Mode of action uncovered for the specific reduction of methane emissions from ruminants by the small molecule 3-nitrooxypropanol. Proc. Natl. Acad. Sci. USA 113:6172-6177. https://doi.org/10.1073/pnas.1600298113.

Ellis, J. L., J. Dijkstra, E. Kebreab, A. Bannink, N. E. Odongo, B. W. McBride, and J. France. 2008. Aspects of rumen microbiology central to mechanistic modelling of methane production in cattle. J. Agric. Sci. 146:213-233. https://doi.org/10.1017/ S0021859608007752.

Haisan, J., Y. Sun, L. L. Guan, K. A. Beauchemin, A. Iwaasa, S. Duval, D. R. Barreda, and M. Oba. 2014. The effects of feeding 3-nitrooxypropanol on methane emissions and productivity of Holstein cows in mid lactation. J. Dairy Sci. 97:3110-3119. https://doi.org/ 10.3168/jds.2013-7834.

Haisan, J., Y. Sun, L. L. Guan, K. A. Beauchemin, A. Iwaasa, S. Duval, M. Kindermann, D. R. Barreda, and M. Oba. 2017. The effects of feeding 3-nitrooxypropanol at two doses on milk production, rumen fermentation, plasma metabolites, nutrient digestibility, and methane emissions in lactating Holstein cows. Anim. Prod. Sci. 57:282-289. https://doi.org/10.1071/AN15219.

Hall, M. B. 2009. Determination of starch, including maltooligosaccharides, in animal feeds: Comparison of methods and a method recommended for AOAC collaborative study. J. AOAC Int. 92:42-49. https://doi.org/10.1093/jaoac/92.1.42.

Hristov, A. N., and A. Melgar. 2019. Variability in the relationship between enteric methane emission and dry matter intake in dairy cows. Page 82 in Proc. 7th Int. Greenhouse Gas Anim. Agric. Conf, Iguassu Falls, Brazil. A. Berndt, L. G. Pereira Ribeiro, and A. L. Abdala, ed. Embrapa Southeast Livestock, São Carlos, SP, Brazil.

Hristov, A. N., J. Oh, F. Giallongo, T. Frederick, M. T. Harper, H. L. Weeks, A. F. Branco, P. J. Moate, M. H. Deighton, S. R. O. Williams, M. Kindermann, and S. Duval. 2015a. An inhibitor persistently decreased enteric methane emission from dairy cows with no negative effect on milk production. Proc. Natl. Acad. Sci. USA 112:10663-10668. https://doi.org/10.1073/pnas.1504124112. 
Hristov, A. N., J. Oh, F. Giallongo, T. Frederick, H. Weeks, P. R. Zimmerman, M. T. Harper, R. A. Hristova, R. S. Zimmerman, and A. F. Branco. 2015b. The use of an automated system (GreenFeed) to monitor enteric methane and carbon dioxide emissions from ruminant animals. J. Vis. Exp. 103:e52904. https://doi.org/10.3791/ 52904.

Hungate, R. E. 1967. Hydrogen as an intermediate in the rumen fermentation. Arch. Mikrobiol. 59:158-164. https://doi.org/10.1007/ BF00406327.

Janssen, P. H. 2010. Influence of hydrogen on rumen methane formation and fermentation balances through microbial growth kinetics and fermentation thermodynamics. Anim. Feed Sci. Technol. 160:1-22. https://doi.org/10.1016/j.anifeedsci.2010.07.002.

Lopes, J. C., L. F. de Matos, M. T. Harper, F. Giallongo, J. Oh, D. Gruen, S. Ono, M. Kindermann, S. Duval, and A. N. Hristov. 2016. Effect of 3-nitrooxypropanol on methane and hydrogen emissions, methane isotopic signature, and ruminal fermentation in dairy cows. J. Dairy Sci. 99:5335-5344. https://doi.org/10.3168/jds.2015 -10832 .

Lourenço, M., E. Ramos-Morales, and R. Wallace. 2010. The role of microbes in rumen lipolysis and biohydrogenation and their manipulation. Animal 4:1008-1023. https://doi.org/10.1017/ S175173111000042X.

Marty, R. J., and D. I. Demeyer. 1973. The effect of inhibitors of methane production on fermentation pattern and stoichiometry in vitro using rumen contents from sheep given molasses. Br. J. Nutr. 30:369-376. https://doi.org/10.1079/BJN19730041.

Martinez-Fernandez, G., S. Duval, M. Kindermann, H. J. Schirra, S. E. Denman, and C. S. McSweeney. 2018. 3-NOP vs. halogenated compound: Methane production, ruminal fermentation and microbial community response in forage fed cattle. Front. Microbiol. 9:1582. https://doi.org/10.3389/fmicb.2018.01582.

Melgar, A., M. T. Harper, J. Oh, F. Giallongo, M. E. Young, T. L. Ott, S. Duval, and A. N. Hristov. 2020. Effects of 3-nitrooxypropanol on rumen fermentation, lactational performance, and the resumption of ovarian cyclicity in dairy cows. J. Dairy Sci. 103:410-432. https: //doi.org/10.3168/jds.2019-17085.

Melgar, A., C. F. A. Lage, K. Nedelkov, S. E. Räisänen, H. Stefenoni, M. E. Young, X. Chen, J. Oh, S. Duval, M. Kindermann, N. D. Walker, and A. N. Hristov. 2019. Effects of 3-nitrooxypropanol on enteric methane emission and lactational performance of dairy cows. J. Dairy Sci. 102(E-Suppl. 1):428. (Abstr.)

Melgar, A., K. Nedelkov, C. M. M. R. Martins, K. C. Welter, X. Chen, M. T. Harper, S. Duval, and A. N. Hristov. 2018. Palatability of total mixed rations containing 3-nitrooxypropanol for lactating dairy cows. J. Dairy Sci. 101(E-Suppl. 2):92. (Abstr.)

Nagaraja, T. G., C. J. Newbold, C. J. Van Nevel, and D. I. Demeyer. 1997. Manipulation of ruminal fermentation. Pages 523-632 in The Rumen Microbial Ecosystem. P. N. Hobson and C. S. Stewart, ed. Chapman and Hall, London, UK.

NRC. 2001. Nutrient Requirements of Dairy Cattle. 7th rev. ed. Natl. Acad. Press., Washington, DC.

Nousiainen, J., K. J. Shingfield, and P. Huhtanen. 2004. Evaluation of milk urea nitrogen as a diagnostic of protein feeding. J. Dairy Sci. 87:386-398. https://doi.org/10.3168/jds.S0022-0302(04)73178-1.

Reynolds, C. K., D. J. Humphries, P. Kirton, M. Kindermann, S. Duval, and W. Steinberg. 2014. Effects of 3-nitrooxypropanol on methane emission, digestion, and energy and nitrogen balance of lactating dairy cows. J. Dairy Sci. 97:3777-3789. https://doi.org/ 10.3168/jds.2013-7397.

Rico, D. E., and K. J. Harvatine. 2013. Induction of and recovery from milk fat depression occurs progressively in dairy cows switched between diets that differ in fiber and oil concentration. J. Dairy Sci. 96:6621-6630. https://doi.org/10.3168/jds.2013-6820.
Romero-Pérez, A., E. K. Okine, S. M. McGinn, L. L. Guan, M. Oba, S. M. Duval, M. Kindermann, and K. A. Beauchemin. 2014. The potential of 3-nitrooxypropanol to lower enteric methane emissions from beef cattle. J. Anim. Sci. 92:4682-4693. https://doi.org/10 $.2527 /$ jas.2014-7573.

Romero-Pérez, A., E. K. Okine, S. M. McGinn, L. L. Guan, M. Oba, S. M. Duval, M. Kindermann, and K. A. Beauchemin. 2015. Sustained reduction in methane production from long-term addition of 3-nitrooxypropanol to a beef cattle diet. J. Anim. Sci. 93:17801791. https://doi.org/10.2527/jas.2014-8726.

Russell, J. B., and S. A. Martin. 1984. Effects of various methane inhibitors on the fermentation of amino acids by mixed rumen microorganisms in vitro. J. Anim. Sci. 59:1329-1338. https://doi .org/10.2527/jas1984.5951329x

Sjaunja, L. O., L. Baevre, L. Junkkarinen, J. Pedersen, and J. Setälä. 1990. A Nordic proposal for an energy corrected milk (ECM) formula. Pages 156-157 in 27th Session of the International Commission for Breeding and Productivity of Milk Animals, Paris, France. Wageningen Academic Publishers, Wageningen, the Netherlands.

Sutton, J. D., M. S. Dhanoa, S. V. Morant, J. France, D. J. Napper, and E. Schuller. 2003. Rates of production of acetate, propionate, and butyrate in the rumen of lactating dairy cows given normal and low-roughage diets. J. Dairy Sci. 86:3620-3633. https://doi .org/10.3168/jds.S0022-0302(03)73968-X.

Trei, J. E., G. C. Scott, and R. C. Parish. 1972. Influence of methane inhibition on energetic efficiency of lambs. J. Anim. Sci. 34:510515. https://doi.org/10.2527/jas1972.343510x.

van Lingen, H. J., C. M. Plugge, J. G. Fadel, E. Kebreab, A. Bannink, and J. Dijkstra. 2016. Thermodynamic driving force of hydrogen on rumen microbial metabolism: A theoretical investigation. PLoS One 11:e0161362. https://doi.org/10.1371/journal.pone.0161362.

Van Soest, P. J. 1963. Ruminant fat metabolism with particular reference to factors affecting low milk fat and feed efficiency. A review. J. Dairy Sci. 46:204-216. https://doi.org/10.3168/jds.S0022 -0302(63)89008-6.

Van Soest, P. J., J. B. Robertson, and B. A. Lewis. 1991. Methods for dietary fiber, neutral detergent fiber, and nonstarch polysaccharides in relation to animal nutrition. J. Dairy Sci. 74:3583-3597. https://doi.org/10.3168/jds.S0022-0302(91)78551-2.

Van Wesemael, D., L. Vandaele, B. Ampe, H. Cattrysse, S. Duval, M. Kindermann, V. Fievez, S. De Campeneere, and N. Peiren. 2019. Reducing enteric methane emissions from dairy cattle: Two ways to supplement 3-nitrooxypropanol. J. Dairy Sci. 102:1780-1787. https://doi.org/10.3168/jds.2018-14534.

Vyas, D., A. W. Alemu, S. M. McGinn, S. M. Duval, M. Kindermann, and K. A. Beauchemin. 2018. The combined effects of supplementing monensin and 3-nitrooxypropanol on methane emissions, growth rate, and feed conversion efficiency in beef cattle fed high forage and high grain diets. J. Anim. Sci. 96:2923-2938. https:// doi.org/10.1093/jas/sky174.

Vyas, D., S. M. McGinn, S. M. Duval, M. K. Kindermann, and K. A. Beauchemin. 2016. Optimal dose of 3-nitrooxypropanol for decreasing enteric methane emissions from beef cattle fed high-forage and high-grain diets. Anim. Prod. Sci. 58:1049-1055. https://doi .org/10.1071/AN15705.

Wang, M., X. Z. Sun, P. H. Janssen, S. X. Tang, and Z. L. Tan. 2014 Responses of methane production and fermentation pathways to the increased dissolved hydrogen concentration generated by eight substrates in in vitro ruminal cultures. Anim. Feed Sci. Technol. 194:1-11. https://doi.org/10.1016/j.anifeedsci.2014.04.012.

Wolin, M. J. 1960. A theoretical rumen fermentation balance. J. Dairy Sci. 43:1452-1459. https://doi.org/10.3168/jds.S0022 -0302(60)90348-9. 